\title{
Narrating organizational spaces
}

\author{
Arja Ropo and Ritva Höykinpuro \\ University of Tampere, Finland
}

\begin{abstract}
Purpose: The purpose of this article is to explore the narrative nature of organizational spaces and how these narratives influence human action. The study introduces a notion of 'narrating space' that emphasizes a narrative construction of space that is dynamic and performative. The study joins the recent material and spatial turn in organization studies where spaces are not considered merely as a container or a context to organizational action, but as a dynamic and active force.
\end{abstract}

Design/methodology/approach: The study draws on the triadic conception of space of Henry Lefebvre (1991). Lefebvre developed three interconnected dimensions of space: conceived, perceived and lived space. Space can be conceived as an abstract architectural plan or perceived through the practice of space. The dimension that integrates these two is the lived space. Spaces are experienced through emotions, imagination and embodied sensations. Instead of being a passive object, spaces become active and performative through the human engagement. They carry narratives that change their form as time passes by. The study embraces aesthetic, embodied epistemology where sensuous perceptions are considered as valid knowledge.

Findings: The study applies an aesthetic and dynamic approach to space and illustrates how spaces carry performative and processual narratives. These narratives are based on lived experience through personal, embodied experience, memories, and sensuous perceptions. The illustrations also show that narratives change over time.

Theoretical implications: A narrating space concept is characterized by being subjective, dynamic, and temporal. Furthermore, it is pointed out that space is constructed through sense-based experiences. A metaphor of an 
amoeba is offered to depict the nature of the phenomenon. The amoeba metaphor points out that space narratives are dynamic and changing. The study adds to a better awareness of space as a sensuous narrative. Beyond being an isolated personal experience, the study and the illustrations enhance a material view to organizational narratives.

Practical implications: The study suggest that managers, architects and designers should take notice of spaces as narratives that involve temporal and sensuous experiences when planning and (re)designing work environments. Due to the subjective and temporal nature of organizational spaces they are manageable only to a limited extent. Therefore, to appreciate an active narrating nature of organizational spaces, employee involvement in planning and (re)designing spaces is encouraged.

Originality/value: First, the article enhances the awareness of organizational spaces as sensuous narratives. Second, it adds a material aspect to narratives. Third, it advances an aesthetic and embodied approach to narrative organization research.

Keywords: narrative, space, performative, process, aesthetics, Lefebvre

\section{Introduction}

This article is about organizational (work)spaces, especially about the narrative nature of space. Instead of treating space as dead /silent, fixed and immobile (Foucault, 1980), we explore space as an active, dynamic and performative force that influences human action (Beyes and Steyaert, 2011; Lefebvre, 1991; Tyler and Cohen, 2010). Our intake on space is informed by the recently grown interest in materiality and spatiality in organizations and management (e.g. Carlile, Nicolini, Langley \& Tsoukas 2014; De Vaujany and Mitev, 2013; Van Marrewijk and Yanow, 2010). We do not give space an independent agency role, though, but rely on aesthetic organization approach to organizations (e.g. Strati, 1999) that argues for embodied experience to understand organizational life. For the spaces to become active narrators, a personal experience is needed through sensuous perceptions, 
evoked feelings and emotions, and memories of space (De Vaujany and Vaast, 2013; Martin, 2002; Ropo, Sauer \& Salovaara, 2013; Ropo, Salovaara, Sauer \& De Paoli, 2015; Van Marrewijk, 2011; Våland, 2010). By being performative in refers to human action, the narratives are processual and changing. The same space may narrate a different story at different times. Once experienced as dangerous or with fear, the same space may feel neutral or indifferent as time elapses and memories fade. We suggest that narrating spaces are like amoebas that are in a constant state of becoming. Like the moves of an amoeba, space experiences are difficult to anticipate or control.

We develop the argument of narrating spaces through the following chapters. First we discuss how materiality and spatiality has entered the organization and management studies field. To overcome a managerially or architecturally determined causal relationship between the material space and human action, we rely on Lefebvre's triadic concept of space as conceived, perceived and lived, which we connect with aesthetic epistemology and process ontology. We emphasize that spaces narrate through embodied experiences of space by evoking sensations and memories. We illustrate this in two instances: a railway underpass and an office corridor that both narrated once a 'horror' story, but that have later faded away or being replaced by other narrations. Finally, we offer a metaphor of an amoeba to convey the nature of the phenomenon of narrating spaces and discuss its implications to theory and practice.

\section{Material and spatial turn in organization studies}

During the past ten years organization studies have experienced a 'material turn' (Barad, 2003; Carlile et al., 2014; Dale, 2005; Orlikowski, 2007) and especially a 'spatial turn' (Beyes and Steyaert, 2012; Van Marrewijk and Yanow, 2010). After the strong social constructionist emphasis, also materiality has been increasingly argued to influence human action. It has been shown that material objects such as water-coolers, (Fayard and Weeks, 2007), copy machines (Humphries and Smith, 2014) and smart phones (Orlikowski, 2007) influence people and their actions. Also material spaces and the built environment have been found to be powerful in organizing work life (Clegg and Kornberger, 2006; Dale, 2005; Dale and Burrell, 2008; De 
Vaujany and Mitev, 2013; Van Marrewijk and Yanow, 2010).

Organizational space studies have grown from different paradigmatic backgrounds. Three major literature streams have been identified (Ropo et al., 2013): first, an objective approach studying the physical environment from architectural and managerial perspective ("this is how it is planned to work and effect") (e.g. Elsbach and Pratt, 2007); second, a subjectively oriented approach to space ("this is how we experience and interpret it") (e.g. Martin, 2002; Strati, 1992, 2007; Våland, 2010) and third, a critical, poststructuralistic approach that emphasizes how buildings and spatial arrangements have a way of bringing about and reinforcing workplace power relations (Clegg and Kornberger, 2006; Dale, 2006; Dale and Burrell, 2008; Van Marrewijk and Yanow, 2010; Zhang and Spicer, 2014). The recent interest in the study of organizational spaces pursues an integrative effort to connect a more objective, managerial and architectural approach to physical work environment with understanding the symbolic meaning of physical spaces as social encounters (Dale and Burrell, 2000; Van Marrewijk and Yanow, 2010).

Our study draws on the triadic conception of space introduced by the French sociologist Henry Lefebvre (1991). Lefebvre's space concept has been widely used and elaborated in organization studies (Beyes and Steyaert, 2011; Ropo et al., 2013, 2015; Taylor and Spicer, 2007; Zhang and Spicer, 2014; Wasserman and Frenkel, 2011). Lefebvre's space concept has three 'natures': first, a conceived nature seen in abstract plans of architects and in mathematical measures of building layouts; second, a perceived nature in peoples' practical use of the space; and third, a lived nature experienced through the human body as in sensations, emotions, memories and imagination. To Lefebvre, these three are simultaneously valid. In conjunction to this view, living in space makes it temporally emerging and dynamic (Hernes, Bakken \& Olsen, 2006). 


\section{Methodological approach: Aesthetic and performative narratives}

Beyes and Steyart (2011) and Tyler and Cohen (2010) have further elaborated Lefebvre's emergent nature of space toward a 'performative' approach to space. Space is a source, carrier and enabler of emotions, memories, incidents and actions. Referring to Lefebvre, Beyes and Steyaert (2011) maintain that space is an active force (p. 47) enacted through material, embodied and affected 'spacing' (p. 48). They emphasize that space is a dynamic process, in a constant state of becoming.

Despite the topics of space and place enjoying a growing interest, Elsbach and Pratt (2007) conclude in their review of the physical environment in organizations that connection between the senses (aesthetic sensibilities) and the physical environment is lacking. However, as of now there is almost a canonized body of knowledge on studying space and subjective, sense-based experiences of it (e.g. Martin, 2002; Strati, 1999, 2007; Taylor and Spicer, 2007; Van Marrewijk, 2011; Våland, 2010). Literature shows how spaces directly, indirectly, symbolically or through evoking emotions influence human action (Dale and Burrell, 2008; De Vaujany and Vaast, 2013; Ropo et al., 2013, 2015; Van Marrewijk and Yanow, 2010). Van Marrewijk (2011) used ethnographic accounts as narratives and complemented pictures to give a voice to people's aesthetic experiences on the spaces. Martin (2002) explored how an elderly home is constructed through different sights, smells and sounds. Based on in-depth interviews, Hirschman, Ruvio and Belk (2012), while studying garages, emphasize the role of memory in meaning making of the spaces. Strati (2007) points out the importance of sensible, embodied knowledge in learning how to operate in a secretarial office or how to balance bodily movements in a sawmill or in a roofing firm. Taylor and Spicer (2007) provide a narrative review of organizational spaces concluding to three different categories of space: space as distance, space as the materialization of power relations, and space as lived experience. Spaces in these studies are not independent agencies, nor are they considered as passive material containers, but spaces gain their performing nature in relation to human engagement: space needs to be 'given voice' (Yanow, 2010); we need to 'read the ruins' (Dale and Burrell, 2011) and 'listen to the walls talk' (De Vaujany and Vaast, 2013). 
From the aesthetic perspective spaces are not only perceived as built objects isolated from the users, but they are primarily experienced and felt as subjective and sensuous. Spaces trigger and carry sensuous perceptions and embodied memories that influence our way of being. These findings encourage elaborating on employees' aesthetic, sense-based perceptions of workspaces. Sensations typically refer to embodied, physical stimuli, such as 'dark' and 'light'. Perceptions, on the other hand, involve psychological processes of meaning making, experience, interpretation, judgement, and memory. Schiffman (2001) emphasizes an integrative approach to sensation and perception to understand social phenomena, such as experience of work environment. From a phenomenological perspective (e.g. Merleau-Ponty, 1946/1962/2012) the concept experience goes beyond sensations. A recent study of embodied experience on space involves issues, such as staying or lingering that refers to bodily presence, reflecting backwards that refers to memorizing and finally, doing or crafting that refers to concrete activity in the space (Ropo et al., 2013).

In summary, by emphasizing embodied sensations, emotions and memory in experiencing space, this paper joins the discourse of organizational aesthetics to understand how people perceive issues, things, other people and environments as feeling and sensing human beings (Taylor and Hansen, 2005). Organizational aesthetics assumes that human senses and perceptions play a major role in conceiving, perceiving and living the work environment: entering a workspace, let say, an office, can trigger joyful/scary/angry memories through a sight or a smell, which influences the person's way of being in the place and perceiving other people and issues. By applying aesthetics, we refer to a way of knowing as a felt experience through the body in connection with the intellectual knowing through the mind. When talking about aesthetics we do not refer to beauty or the arts although art is a field whereto aesthetic knowing lends itself (Hansen, Ropo and Sauer, 2007). We build on Strati $(1999,2007)$ who argues that felt meanings and felt experiences are valid sources of scholarly knowledge production.

Narrative research is largely based on a constructionist approach. Here, we focus on producing the organizational space through a narrative - told by the spaces themselves through the experiences of the people engaged in them. A 
narrative approach is increasingly used in management and organization studies. However, the definition what constitutes a narrative involves various aspects. A traditional view of a narrative is that the storyteller has a purpose of telling the story, and that people tend to recall the things that have somehow been meaningful for them. Hence, a story has an orientation, events, an end and conclusions, all following a chronological order, (e.g. Riessman, 2008; Vaara, 2002). Typically, a story has actors and thus, it may include multiple voices. Narratives and actors are commonly connected to people. What is different in this study is that we suggest that also organizational space (workplaces) have a voice (cf. Dale and Burrell, 2011; De Vaujany and Vaast, 2013; Yanow, 2010). Beyond incorporating sensuous perceptions and physical encounters, organizational spaces convey memories that can be recalled, and that stimulate storytelling. For instance, a person can recall when she/he entered an office for the very first time (like a snapshot), and even tell a story about it with some visual methods (Höykinpuro and Ropo, 2014). Thereafter different things may happen in the same office or in the same corridor, the same space evoking different emotions and memories. Hence, the story has a temporal and dynamic nature. Spatial narratives change over time depending on the time and context when they are narrated.

\section{Illustrations of narrating spaces}

Next, we turn to illustrate what we mean by 'narrating space' by providing two instances where spaces carry performative narratives. These are autoethnographic accounts and are not meant to provide any generalizations. However, beyond being mere isolated personal experiences, they give a glimpse of how spaces produce narratives through aesthetic experiences and how they may change. In so doing the accounts add a material and processual aspect to organizational narratives. The first narrative is of a pedestrian who keeps memorizing experiences of entering and walking through a railway underpass by way the city has organized the city traffic.

\section{Pedestrian experience on railway underpass}

- Picture 1a and 1b. Railway underpass - 
"I remember this underpass since my childhood. When I enter it from the city centre I see nothing but darkness (Picture 1a). I hear a lot of noises because of the cars driving fast through the underpass. The same underpass is used by pedestrians, cyclist and cars, and it is such a narrow tunnel. It looks quite scary with its dark 'mouth'. I remember reading in the newspaper of some hideous crimes committed there. When I walk through the underpass the noise is really loud echoing from the concrete walls. I have to be cautious of the cyclists because the space for both the pedestrians and the cyclists is so narrow. I can smell the exhaust fumes and they almost make me sick. Once I saw that there were some elderly tourists passing through the tunnel and they covered their eyes and ears while walking through. Going through the underpass becomes gets, however, a little bit better and less uninviting after a couple of minutes when I can see the light coming from the other end of the tunnel. After a few minutes I will get out of the underpass and see the sky. What a relief!

Often, if possible, I try to avoid the tunnel and take another, only longer, way. Lately, a new underpass has been built, but it means taking a longer route to the city center. Luckily it is for pedestrians and cyclists only. Anyway, it takes some more minutes to choose that way and when I am in a hurry I have to save all the time I can." (AA)

The second narrative is of an employee whose experience of an office corridor has made him/her change the walking route, followed by a later more neutral and calm corridor narrative.

\section{Employee experience on office corridor}

- Picture $2 \mathrm{a}$ and $2 \mathrm{~b}$. An office corridor -

"I have been working in the same building for many years and have various kinds of experiences and memories of the place. The same spaces feels different over the years. There was a time, when I used a side door to go to my office because it was too frightening to pass some people in the corridor (Picture 2a). A bad taste in my mouth with an accelerated heartbeat accompanied me every day. Because of the continued uncomfortable encounters in the hallway and behind the closed doors with some of my 
colleagues who repeatedly and systematically downplayed and ridiculed me as a scholar, the corridor became a nest of evil and bad will. Now, after years, the same corridor reminds me vaguely of the earlier feelings, but only as an old sediment of sensuous experiences that may eventually fade away if not repeated.

I am still working in the same building, but on a different floor. The corridor looks pretty much the same, but I have different experiences of it. Imagine this: It is Thursday afternoon at $2 \mathrm{pm}$. I approach my office. I am faced with an empty corridor (Picture 2b). I cannot see any other people. Doors are closed although I can easily see through the partly transparent doors, if someone is in the room. No voices or any other sounds cannot be heard. I can only sense that there are people behind the doors, talking to their phones or to someone in the room at a lowered voice. My feeling of the sight and soundless of the space makes me go to my office quickly without making any noise, or saying hello. Sometimes the smell of coffee gives me a sign that there are some living creatures nearby. If not coffee, I can almost sense a sterile hospital smell in the corridor, maybe due to the floor detergents. The surfaces are hard and shiny with touches of steel and glass. This feels like a deserted place." (BB)

These two instances give some hints of how the spaces carry narratives through our lived experiences: the oppressing railway underpass and the inescapable office corridor. Common to both of them is that they are strongly informed by sensuous perceptions. Along with evoking emotions and memories, smelling, hearing, seeing, touching, and tasting are central in these narrating spaces.

\section{Discussion and conclusions}

We have explored in this article the notion of letting a built environment, such as an organizational space have a narrative voice: under what kind of methodological premises that might be done and how this view is connected to the current theorizing on organizational space and materiality of organizations in general. First, we have separated ourselves from the 
common view of spaces as fixed and static, and have joined the proponents that argue that spaces are active, performative and temporal (e,g. Beyes and Steyaert, 2011; Dale and Burrell, 2008; Lefebvre, 1991; Zhang and Spicer, 2014). Second, we have based our analysis on understanding organizational spaces as aesthetic spheres that emphasize the importance of giving notice to emotional sensations and memorizing (e.g. Strati, 1999; Wasserman and Frenkel, 2011). Finally, we have stretched beyond the common view of giving the active narrator status only to human beings and argue that spaces do have a voice, also. However, the physical built spaces do not tell a story as independent material entities, but need human engagement. The spaces start to talk as people get engaged with them by practicing and living (in) the spaces. The narrating spaces tell stories through people's aesthetic experiences, through their sensuous feelings, sights, smells, noises, voices, feels of touch, maybe even taste that come to the sensing body and the conscious mind while being in the space. The aesthetic body and the conscious mind are intertwined and make the spatial narration complete.

The study shows how organizational spaces are narrated as a lived experience through personal, embodied experiences, memories, and sensuous perceptions. Also, it shows that experiencing a space may change as time passes by - spaces carry dynamic, temporal narratives. To further describe and analyse the concept of narrating space we use an image of an amoeba (Figure 1).

- Figure 1. Amoeba as a metaphor of narrating space -

An amoeba can be described as an organism with an indefinite and changing shape. An amoeba keeps changing its form with little control from the outside. It has no fixed structure, which means that it is difficult to control and the efforts to manipulate can have unexpected outcomes. The characteristics of an amoeba as a metaphor point out the key features of the narrating space concept. The limbs of the amoeba can be considered to depict the five senses through which the organizational spaces are experienced; they keep changing constantly with different intensities. Along with the sensuous perceptions and practice in the space, emotions grow. Spaces get attached with emotions and sensations, which make the space 'talk'. Narrating 
workspace influences social action. Space becomes performative. For example, one may start avoiding to use a space where uncomfortable experiences were felt or distressed noise was heard.

The dynamism of the space narration occurs between people, across time and as to the intensity of the different senses and memories. For example, some people are more inclined to visual than auditory or other sensuous stimuli. Also, the same space can be experienced differently even by the same person at another point of time. Furthermore, the space can evoke different senses to a varying extent. For example, sights and sounds may be dominant dimensions in some spaces while others may evoke more metaphorical sensuous feelings, such as having 'a bad taste' in the mouth without the actual physical taste.

To reiterate, the concept narrating space was developed here connected with the following features: it is subjective, dynamic, and temporal. Furthermore, it is based on aesthetic sense perceptions, emotions and memories. A metaphor of an amoeba is suggested to describe the dynamic nature of the narrating space.

\section{Practical implications and future research}

The study has the following practical implications. First, it adds to the managerial understanding a better awareness of the organizational spaces as people's sensuous experiences. Thus, it captures the user perspective instead of a provider perspective that is common in architecturally managed building processes. Second, managers, architects and designers could take the role of an employee in the workplace and use their own temporal and sensuous experiences when planning and (re)designing work environments (e.g. Van Marrewijk, 2011). Third, due to the subjective and temporal nature of organizational spaces their experience is hardly manageable in a traditional way. Therefore, employee involvement in planning, designing and (re)designing work environments is encouraged. We conclude that companies, cities and governments could gain better outcomes if they cooperated with employees and citizens in planning and designing the spaces. 
This article provides ideas for future research. The concept narrating space should be empirically further developed and elaborated on. A larger number of narratives in different space contexts would provide more specific characterizations of the temporality, the varying intensity of the senses, and variations between people and contexts. To elaborate on the narrating concept, empirical studies should concentrate more specifically on various senses and their connectedness with emotions and memories. Finally, one direction for future research could be to elaborate on how narrating spaces affect human action in different work environments.

\section{References}

Barad, K. (2003), "Posthumanist performativity: toward an understanding of how matter comes to matter", Signs: Journal of Women in Culture and Society, Vol. 28 No. 23, pp. 801-831.

Bell, E., Warren, S. and Schroeder, J. (Eds) (2014), The Routledge Companion to Visual Organization, Routledge, London and New York.

Beyes, T. and Steyaert, C. (2011), "Spacing organization: nonrepresentational theory and performing organizational space", Organization, Vol. 19 No.1, pp. 45-61.

Carlile, P., Nicolini, D., Langley, A. and Tsoukas, H. (Eds) (2013), How Matter Matters: Objects, Artifacts and Materiality in Organization Studies, Oxford University Press, Oxford.

Dale, K. (2005), "Building a social materiality: spatial and embodied politics in organizational control", Organization, Vol.12 No. 5, pp. 649-678.

Dale, K. and Burrell, G. (2011), "Disturbing structure: reading the ruins", Culture and Organization Vol. 17 No. 2, pp. 107-121.

Dale, K. and Burrell, G. (2008), Spaces of Organization and the Organization of Space, Palgrave Macmillan, Basingstoke. 
De Vaujany, F.-X. and Mitev, N. (Eds) (2013), Materiality and Space. Organizations, Artefacts and Practices, Palgrave, New York.

De Vaujany, F.-X., and Vaast, E. (2013), "If these walls could talk: the mutual construction of organizational space and legitimacy", Organization Science. Retrieved Dec 15, 2015 at:

www.dx.doi.org/10.1287/orsc.2013.0858.

Elsbach, K.D. and Pratt, M.G. (2007), "The physical environment in organizations", The Academy of Management Annals Vol. 1 No.1, pp. 181224.

Fayard, A.L. and Weeks, J. (2007), "Photocopiers and water-coolers: The affordances of informal interaction", Organization Studies, Vol. 28, No. 5, pp. 605-634.

Foucault, M. (1980), Power/Knowledge. Selected interviews \& other writings 1972-1977, Edited by Colin Gordon, Pantheon Books, New York.

Hansen, H., Ropo, A., \& Sauer, E. (2007), "Aesthetic leadership", Leadership Quarterly, Vol. 18., pp. 544-60.

Hernes. T., Bakken, T., \& Olsen, P.I. (2006), "Spaces as process: Developing a recursive perspective on organizational space", in Clegg, S.R. and Kornberger, M. (Eds), Space organizations and management theory (pp. 4463), Liber and Copenhagen Business School Press, Copenhagen.

Hirschman, E.C., Ruvio, A. \& Belk, R.W. (2012), "Exploring space and place in marketing research. Excavating the garage", Marketing Theory, Vol. 12, No. 4, pp. 369-389.

Humphries, C. and Smith, A.C.T. (2014), "Talking objects: towards a postsocial research framework for exploring object narratives", Organization, Vol. 21 No. 4, pp. 477-494.

Höykinpuro, R. and Ropo, A. (2014), "Visual narratives on organizational space", Journal of Organizational Change Management, Vol. 27, No 5, pp. 780-792. 
Lefebvre, H. (1991), The Production of Space, Blackwell, Oxford. Martin, Y. (2002), "Sensations, bodies, and the spirit of a place: aesthetics in residential

organizations for the elderly", Human Relations Vol. 55 No.7, pp. 861885. Merleau-Ponty, M. (1946/1962/2012), Phenomenology of Perception (translated by Colin Smith),

Humanities Press, New York. Orlikowski, W. J. (2007), "Sociomaterial practices: exploring technology at work", Organization

Studies, Vol. 28, pp. 1435-1448.

Riessman, K. K. (2008), Narrative Methods for the Human Sciences, Sage, London, UK.

Ropo, A., Salovaara, P., Sauer, E., \& De Paoli, D. (Eds) (2015), Leadership in Spaces and Places, Edward Elgar, Cheltenham, UK and Northampton, MA, USA.

Ropo, A., Sauer, E., \& Salovaara P. (2013), "Embodiment of leadership through material place", Leadership, Vol. 9 No. 3, pp. 378-395.

Schiffmann, H. R. (2001), Sensation and perception. An integrative approach, Wiley, New York. Strati, A. (1999), Organization and Aesthetics, Sage, London.

Strati, A. (2007), "Sensible knowledge and practice-based learning", Management Learning, Vol. 38 No. 1, pp. 61-77.

Taylor, S. and Hansen, H. (2005), "Finding form: Looking at the field of organizational aesthetics" Journal of Management Studies, Vol. 42 No.6, pp. 1211-1231.

Taylor, S. and Spicer, A. (2007), "Time for space: a narrative review of research on organizational spaces", International Journal of Management Reviews, Vol. 9 No. 4, pp. 325-346. 
Tyler, M. and Cohen, L. (2010), "Spaces that Matter: Gender Performativity and Organizational Space”, Organization Studies, Vol. 31 No. 2, pp. 175198.

Vaara, E. (2002), "On the discursive construction of success/failure in narratives of post-merger integration", Organization Studies, Vol. 23 No. 2, pp. 211-248.

Van Marrewijk, A. (2011), "Aesthetic experiences of designed organizational space", International Journal of Work Organization and Emotion, Vol. 4, No. 1, pp. 61-77.

Van Marrewijk, A. and Yanow, D. (Eds) (2010), Organizational Spaces. Rematerializing the Workaday World, Edward Elgar, Cheltenham.

Våland, M. (2010), What we talk about when we talk about space, Copenhagen Business School Press, Copenhagen.

Wasserman, V. and Frenkel, M. (2011), "Organizational aesthetics: caught between identity regulation and culture jamming", Organization Science, Vol. 22 No. 2, pp. 503-521.

Yanow, D. (2010), "Giving voice to space: academic practices and the material world", in Van Marrewijk, A. and Yanow, D. (Eds) Organizational Spaces. Rematerializing the Workaday World (pp.139-158), Edward Elgar, Cheltenham, UK and Northampton, MA, USA.

Zhang, Z. and Spicer, A. (2016), “'Leader, you first': The everyday construction of hierarchical space in a Chinese bureaucracy", Human Relations, Vol. 67, No. 6, pp. 739-762. 


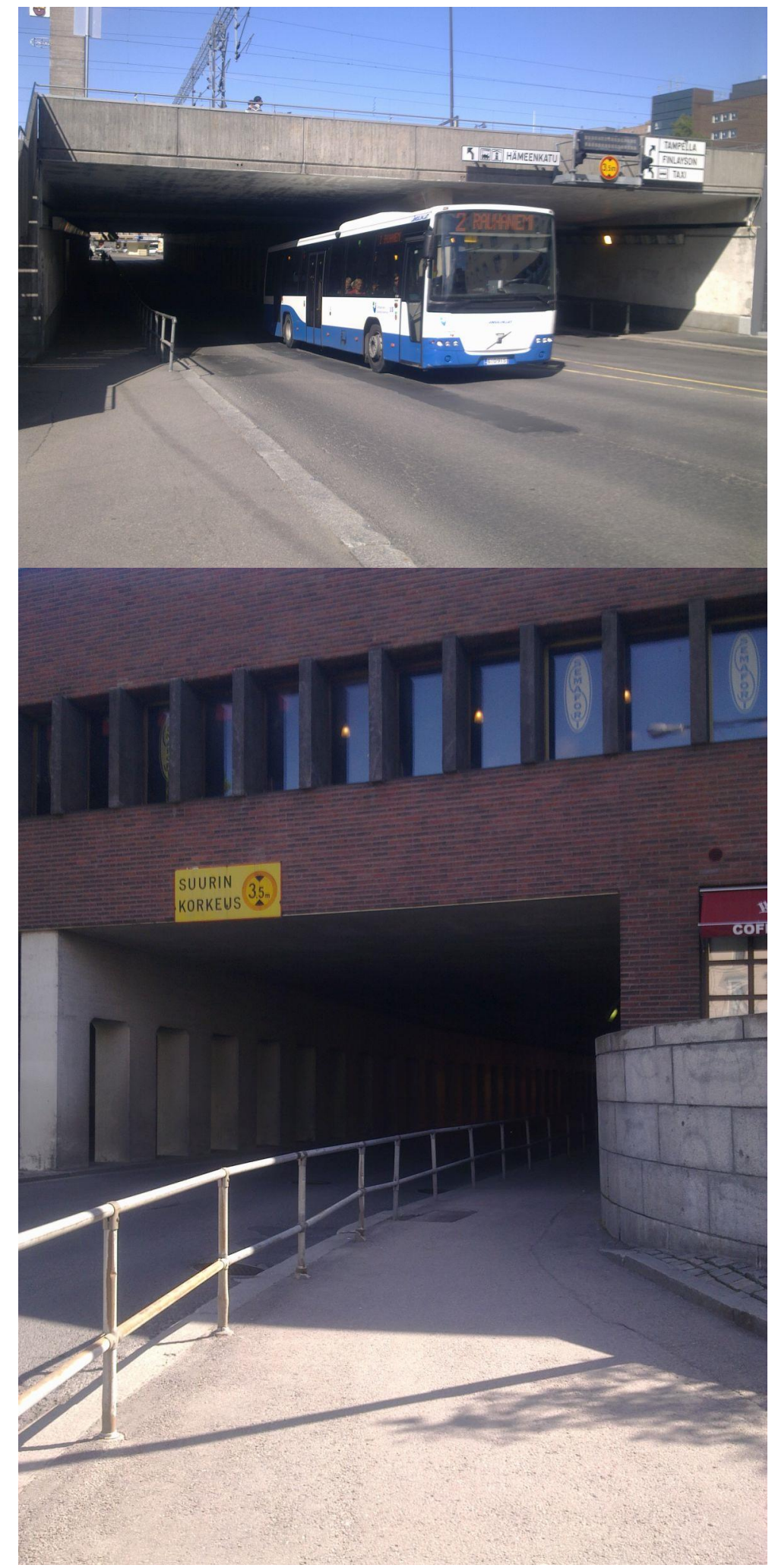

Picture 1a and 1b. Railway underpass 


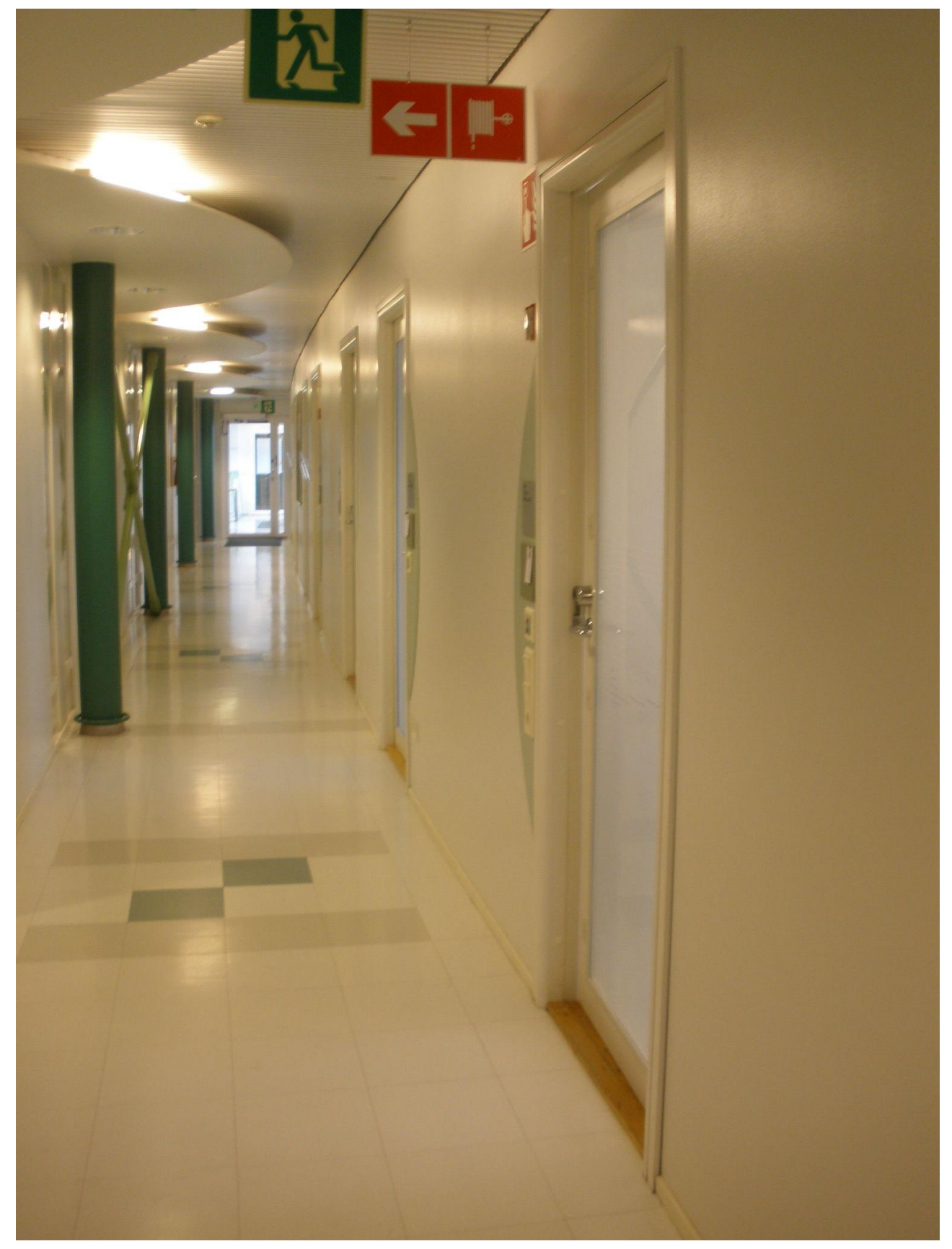




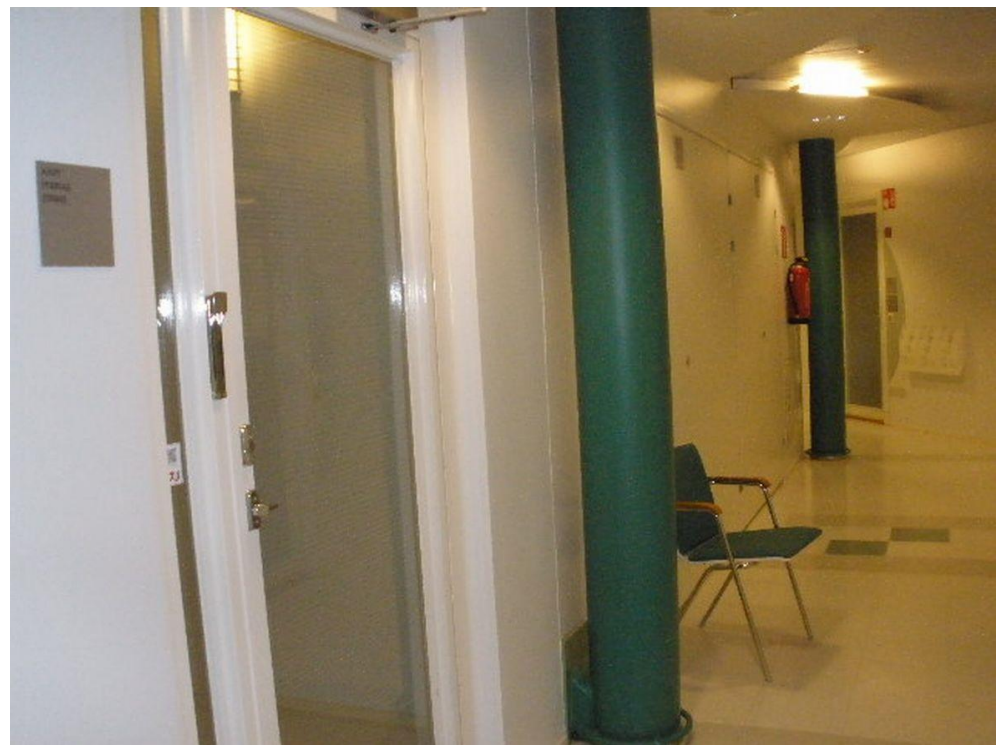

Picture $2 \mathrm{a}$ and $2 \mathrm{~b}$. Office corridor

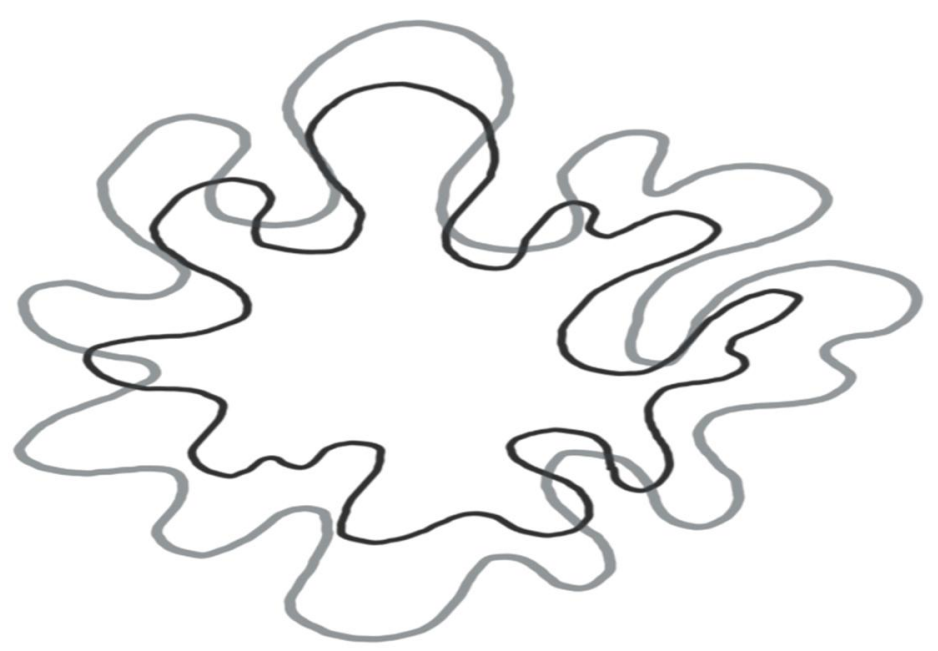

Figure 1. Amoeba as a metaphor of narrating space 